\title{
A Preliminary Analysis of the Teaching Reform of Marxist Philosophy in Colleges and Universities
}

\author{
Jin Lijing \\ School of Marxism, Baicheng Normal University, Baicheng, China \\ jinlijing190@126.com
}

Keywords: Colleges and Universities, Marxist Philosophy, Teaching Reform, Measures

\begin{abstract}
Marxist philosophy is of great significance to the improvement of scientific and cultural quality of college students and the cultivation of their independent thinking ability. Since the reform and opening up, many colleges and universities in our country have made certain achievements in the educational reform of Marxist philosophy. However, many problems exposed in practical teaching have gradually attracted the attention of scholars, including neglecting the essence of philosophy, lacking epoch, neglecting individual value, losing innovation and so on. In this paper, the author will discuss the current situation of the reform of Marxist philosophy education in colleges and universities, analyze the problems and shortcomings, at the same time, the author will explain the necessity of the reform of Marxist philosophy teaching, and put forward the corresponding reform measures, so as to provide reference materials for the teaching reform of Marxist philosophy in colleges and universities.
\end{abstract}

\section{Introduction}

The principle of Marxist philosophy is one of the basic courses of ideological and political education in colleges and universities, that pays attention to the development of college students' philosophical thinking ability, strives to improve the spirit of skepticism and creativity of college students, and it is imperative to carry out educational reform to maintain the authority and lasting vitality of Marxist philosophy. At present, colleges and universities in our country are also facing the challenges in the teaching of Marxist philosophy, including teaching mode, teaching content, teaching methods and teaching quality, etc. How to improve the timeliness of teaching is also a problem worth exploring. In order to help college students establish a correct outlook on life, world outlook and values, the strength of the reform of Marxist philosophy teaching also needs to be strengthened. Combining the teaching reform with the spirit of philosophical innovation dialectically, it can promote the reform of Marxist philosophy teaching.

\section{The Present Situation of Marxist Philosophy Teaching in Colleges and Universities}

In the past ten years, our country has paid more and more attention to the teaching of Marxist philosophy, which has provided a good environment for the reform of Marxist philosophy teaching in colleges and universities. In particular, both the State and the Ministry of Education have taken strong measures to promote the reform of Marxist philosophy teaching. First of all, in the teaching materials, the compilation of Marxist philosophy textbooks is regarded as a key project by the educational departments of our country, and at the same time, the attention paid to the compilation of Marxist philosophy history, ethics, religious education and so on has been improved. Secondly, in the construction of base, the Ministry of education of our country judges the Marx philosophy subject of some colleges and universities as the key subject of the state, enlarges the support for the reform of Marx philosophy teaching in these colleges and universities, and helps some colleges and universities to establish the key research base of Humanities and social sciences and the innovation base of national philosophy and social science to improve the teaching level of Marx philosophy in colleges and universities[1]. Thirdly, in the construction of expert committees, the Ministry of 
Education has appointed a large number of experts in Marxist philosophy to form a discipline teaching steering committee, a study style building committee and a social science committee. To promote the quality of Marxist philosophy teaching in colleges and universities. Finally, in the aspect of discipline construction, colleges and universities in China stimulate the teaching enthusiasm of Marxist philosophy teachers through various measures of rewards and punishments, and evaluate excellent courses and excellent teachers to promote the construction of Marxist philosophy curriculum.

The problems in the teaching of Marxist philosophy in colleges and universities have been exposed in recent years, mainly including four aspects, first of all, ignoring the essence of philosophy, philosophy is usually taught in colleges and universities as general knowledge. The concrete performance includes relying on the compilation of teaching materials in content and adopting the method of feeding into teaching methods, which results in the teachers philosophy teaching becoming too objective, and the students only take notes and memorize the main points, but they do not master the fundamental method of philosophy. All this goes against the essence of philosophy and deviates from the fundamental goal of teaching. Secondly, the lack of the times, Marxist philosophy has a rigorous structure, strong logic and criticism, and is a reflection of real life, but also the essence of the spirit of the times, and some college students in our country do not have firm beliefs. The lack of rich spiritual home and the fact that the teaching content can not keep up with the pace of the times has led to the gradual disappearance of the realistic critical spirit in the teaching of Marxist philosophy in some colleges and universities. The last is the loss of innovation. The teaching of Marxist philosophy in China includes materialism, dialectics, epistemology, historical view, etc., which combine dialectical materialism with historical materialism. The teaching in colleges and universities has concentrated Marxist philosophy, which leads to the lack of innovation and the lack of contact between the teaching contents and the reality, and the whole classroom appears stiff and empty.

\section{Necessity of Teaching Reform of Marxist Philosophy in Colleges and Universities}

The cultivation of philosophical thinking of college students is closely related to the teaching of Marxist philosophy. As one of the compulsory courses for college students, Marxist philosophy shoulders the important task of helping college students improve their philosophical thinking ability and cultivating the spirit of skepticism and creativity. The Marxist philosophy teaching in many colleges and universities usually adopts the mode of "teaching by teachers and listening by students", which is based only on textbooks, which leads to the solidification of the thinking of college students. The purpose of teaching is difficult to achieve, and the way of inspecting Marxist philosophy course in colleges and universities is also the standard answer. Students can only answer the questions according to the key points of the answer and can not give full play to their creative thinking, which makes them unable to form philosophical wisdom and thinking. Therefore, in view of this situation, the reform of Marxist philosophy teaching in colleges and universities is very necessary. One of its purposes is to help college students establish a Marxist philosophy outlook on life, world outlook and values, that endows it with a strong sense of historical responsibility, stimulates the interest and enthusiasm of college students in studying Marxist philosophy, changes the mode of thinking, and improves the ability of creativity and independent thinking [2].

The prosperity of the Chinese national culture is also closely related to Marxist philosophy. To realize the great rejuvenation of the Chinese nation, it is necessary not only to master advanced science and technology, but also to have Marxist wisdom. The French philosopher Descartes once told people that the cultural prosperity of the country is closely related to the philosophical innovation of the nation. Philosophy is the foundation for the individual to settle down, the backbone of the nation, and the soul of the nation, and is the embodiment of a national understanding of itself and the maturity of its mental development. To make a country or a nation stand, economic strength is the basis, and the ideological strength is the soul. In order to promote the innovation of national philosophy in our country, it is imperative to reform the teaching of Marxist philosophy. It is necessary not only to create a strong atmosphere for the study of Marxist 
philosophy in colleges and universities, but also to promote the cultivation of talents with Marxist wisdom to make contributions to the great rejuvenation of the Chinese nation and the economic construction of our country.

\section{Concrete Measures for the Reform of Marxist Philosophy Teaching in Colleges and Universities}

Although some achievements have been made in the reform of the Marx philosophy teaching in various colleges and universities, there are still many problems, which have led to the weakening of the practical effects of the teaching of Marxist philosophy and seriously affect the teaching level and quality of the philosophy of Marxist philosophy and the destruction of the reputation of Marxist philosophy. The credibility is reduced and the persuasion is challenged. Colleges and universities need to take practical measures to carry out the reform of Marxist philosophy teaching, which can be started from the following aspects:

\subsection{Changing the Traditional Teaching Idea of Marxist Philosophy and Grasping the Philosophical Nature of Marxist Philosophy.}

Marxist philosophy teaching is abstract and can be regarded as an exchange between teachers and students based on different living circumstances. If we rely on the traditional way of imparting knowledge to carry out Marxist philosophy teaching, which will be divorced from the investigation of the living conditions of both sides and will break away from the investigation of the living conditions of both sides, thus increasing the difficulty of philosophy teaching. Marxist philosophical theory originates from human practice, but the teaching of these theories needs to return to the practice of life in order to judge its practical value. Therefore, in the concrete teaching process, teachers should change the traditional teaching idea, realize that philosophy teaching is not the teaching of abstract principle and objective principle, but need to connect the spiritual world of teachers and students with the bridge of personal life practice, so that students can understand the spirit of life [3]. For students, it is necessary to connect life experience with philosophy, to think about their own survival and development, to determine their ideals, to pay attention to the future of society, and to be their real masters. While guiding students to pay attention to themselves, teachers should help them to grasp the pulse of the times and the laws of world development so as to achieve the unity of reason and reality.

\subsection{Strengthening the Times of Marxist Philosophy Teaching and Absorbing All Kinds of Philosophical Resources in Teaching.}

Because of the monotony of the Marxist philosophy teaching materials used by Chinese colleges and universities, especially the overlapping of many knowledge and middle school politics, including materialism, dialectics, epistemology, history and so on, it is difficult for students to have interest in learning and study hot feelings on the philosophy of Marx, thus enhancing the Modernity of the teaching of Marxist philosophy is very necessary. The concrete way is to combine the teaching material with the classical works, and lead the students into Marx by PPT and video, so that the students can grasp the essence of the classical Marxist philosophy theory and understand the truth of Marxist philosophy. Chinese culture is broad and profound. Teachers can combine Chinese philosophy with Marxist philosophy textbooks, analyze the outstanding ideological achievements of various philosophies, expand students knowledge and stimulate their enthusiasm for learning philosophy, at the same time, that also deepens the students impression of the scientific openness of Marxist philosophy. The epochal nature of Marxist philosophy teaching should be reflected by the philosophy teaching materials closely linked to the times. The compilation of the textbooks should fully absorb the new research achievements of philosophy, so that Marxist philosophy can be closely combined with reality to enhance its persuasiveness and attractiveness [4]. 


\subsection{Introducing a New Teaching Mode of Marxist Philosophy and Carrying out Heuristic Teaching with Various Forms.}

The traditional teaching mode of Marxist philosophy is the teaching of lecturing, and its one-way transmission of information has some drawbacks. Therefore, the reform of Marxist philosophy teaching should adopt a new teaching mode and use the method of heuristic teaching. Let students become the main body of teaching activities, let teachers and students in the teaching ideas can collide with each other to achieve the purpose of teaching mutually. In the course of specific teaching, teachers can allow students to express their views through group discussions, speech competitions, etc., or teachers can lead students to conduct field visits and research activities, taking the group as the unit to collect the data and making the corresponding report after the investigation and discussion, so as to let the students integrate the philosophical knowledge into the thought, indirectly change their thinking mode and enhance their philosophical wisdom[5]. With the development of science and technology, Marxist philosophy courses should also make use of various modern information means, such as the use of the network for online teaching, through network technology to transmit a variety of materials to students, teachers can also make use of various network platforms to communicate with students and grasp the students' thoughts at any time so as to improve the timeliness of teaching.

\subsection{Reforming the Examination Method of Marxist Philosophy Teaching and Adopting Flexible and Varied Methods to Investigate Knowledge.}

The purpose of Marxist philosophy teaching examination is to investigate the actual effect of teaching, and the form of examination also influences the students' learning attitude. The traditional standard answer examination forms often lead to the phenomenon of high scores and low ability [6]. Therefore, the method of curriculum assessment should be changed, and a more flexible and diverse way can be adopted, for example, teachers can use classroom questioning, homework grading and other methods to evaluate students performance in peacetime. The final examination questions should examine the students knowledge and comprehensive ability, the specific grading criteria should be open, and the innovative viewpoint should be encouraged. Teaching evaluation has an important influence on students' learning attitude. Considering the nature of Marxist philosophy, teachers can stimulate students' enthusiasm and change their learning attitude, so as to promote the improvement of its comprehensive quality.

\section{Conclusion}

Marxist philosophy is the study of wisdom, which contains critical spirit and is scientific and contemporary. The teaching of the philosophy of Marx should grasp its characteristics. The concrete measures include changing the traditional teaching idea, grasping the philosophical nature of Marxist philosophy, strengthening the epochal nature of the teaching of Marxist philosophy, absorbing various philosophical resources in teaching, introducing a new type of teaching model, using a variety of forms to carry out heuristic teaching, changing teaching assessment methods, adopting flexible and diverse methods to conduct knowledge inspection, so as to comprehensively improve the teaching level and teaching quality of Marx philosophy.

\section{References}

[1] Zhang Bo. Preliminary discussion about the teaching reform of Marxist philosophy in colleges and universities [A]. Information Engineering Research Institute, USA. Proceedings of 2012 2nd International Conference on Applied Social Science (ICASS 2012) Volume4 [C]. Information Engineering Research Institute, USA, 2012:5.

[2] Wang Xinyan. Reflections on the reform of Marxist philosophy teaching in colleges and universities in China [J]. Wuhan University Journal (Philosophy \& Social Science), 2004(04): 477-481. 
[3] Sun Min. Tentative study on the reform of Marxist philosophy teaching in colleges and universities in China [J]. Journal of Hainan Normal University (Social Sciences), 2014, 27(04): 133-138.

[4] Wang Xiaodan. Walking out of the predicament of philosophy teaching and showing the charm of speculative spirits: reflections on the reform of Marxist philosophy teaching in colleges and universities [J]. Journal of Tangshan Normal University, 2012, 34(01):155-157.

[5] LI Jie, JIANG Diankun. A preliminary analysis on the reform of Marxist philosophy teaching model in colleges and universities [J]. Journal of Changchun University of Science and Technology (Social Sciences Edition), 2012, 7(11):168-169.

[6] A Survey report on the study of Marxist philosophy in Colleges and Universities [J]. Collection of Marxist philosophy, 2015(02):157-173. 